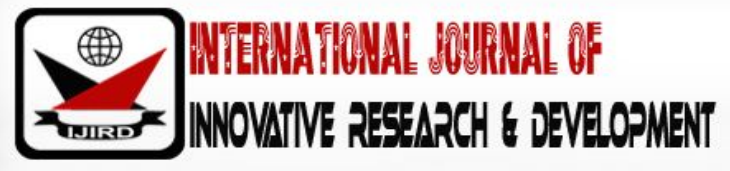

ISSN 2278 - 0211 (Online)

\section{Molecular and Antigenic Characterization of Pigeon Pox Virus Isolated in 2017}

Emad A. Aboul Soud
Chief Researcher, Veterinary Serum and Vaccine Research Institute (VSVRI) Cairo, Egypt
Olfat E. Nakhla
Chief Researcher, Veterinary Serum and Vaccine Research Institute (VSVRI), Cairo, Egypt
Namaa A. Mohamed
Ayatonior Researcher, Veterinary Serum and Vaccine Research Institute (VSVRI), Cairo, Egypt
Ayatollah Ibahim
Eenior Researcher, Veterinary Serum and Vaccine Research Institute (VSVRI), Cairo, Egypt
El Soally, S.A
Army Colonel Veterinarian, Military Veterinary Hospital, Cairo, Egypt

\section{Abstract:}

The current study was conducted to characterize a new isolate of Pigeon pox virus (PPV) isolated from Qaluobeia governate in 2017 based on biological and molecular basis. Isolated strain was propagated and titrated on the chorio-allantoic membrane of specific pathogen free (SPF) embryonated chicken eggs (ECE) showed the characteristic pock lesions of pox virus with titre reached $4.5 \log _{10} E_{1} D_{50}$. The isolated strain was further adapted and propagated on chicken embryo fibroblast cells (CEF) for five successive passages with titre reached $4.3 \log _{10} \mathrm{TCID}_{50}$; the cytopathic effect (CPE) of the propagated virus on $\mathrm{CEF}$ appeared after the $3^{\text {rd }}$ passage as cell rounding and aggregation. The propagated virus was identified using the specific hyper-immune sera by virus neutralization test (VNT) and the neutralizing index (NI) was 2.5 by using homologues PPV hyperimmune sera. DNA was extracted from the identified PPV isolate and the polymerase chain reaction (PCR) used to amplify the 578bp fragment of P4b gene. Sequencing and phylogenetic analysis for the amplified P4b gene product revealed close similarity of the Qaluobeia PPV isolate (PPQ 2017) with the published sequences for PPV in the Gene-bank, and it was classified under geno group A2.

Keywords: Pigeon pox, virus isolate, P4b gene, sequencing, PCR

\section{Introduction}

Pigeon pox disease is caused by pigeon pox virus (PPV) that classified within Family Poxviridae, subfamily Chordopoxvirinae, genus Avipoxvirus (APV) which has the largest and the most divergent genome among the chordopoxvirus genera with many species like PPV, Fowl pox virus (FPV) and Turkey pox virus (TPV) (Andraw, 2012).

Pigeon pox is a slowly spreading disease characterized by the development of discrete proliferative nodular skin lesions (cutaneous form) characterized by nodular lesions on feather free areas of skin such as legs, peak and eye-lids with low mortality and/ or fibrino-necrotic lesions on the mucous membrane of the upper respiratory tract (diphtheritic form) with high mortality. In both forms, gross lesions consist of small vesicles that progress further to nodules and finally scab formation Khan et al. (2009) and Hemanth et al. (2014).

The conventional laboratory diagnosis of FPV is carried out by electron microscope, virus isolation on chorioallantoic membrane (CAM) of embryonated chicken eggs (ECE) and serologic methods as Virus Neutralization test (VNT) on ECE (Islam et al., 2008).

PPV has a double stranded DNA genome which contains a central coding region surrounded by two identical inverted terminal repeat regions. The genome size is $288 \mathrm{kbp}$ approximately and encodes 260 open reading frames Weli et al. (2011). The $4 \mathrm{~b}$ core protein gene (P4b) of APV encoding a protein with a molecular weight of $75.2 \mathrm{kDa}$, is usually chosen for comparative genetic analysis. On the other hand, amplification of the AP-p4b by PCR has often been used as a molecular tool for the detection of avian poxviruses (Manarolla et al., 2010). Based on the phylogenetic analysis of (P4b), APV are divided into three clades; clade A (FPV), clade B (Canary Pox virus), and clade C (Psittacine pox virus) (Offerman et al., 2014). 
The present study provides a report for the sequence analysis of the P4b locus gene amplified from locally isolated PPV in 2017 in order to assess in production of locally prepared vaccines against pox disease in pigeon.

\section{Materials}

\subsection{Pigeon Pox Virus Isolate}

The virus was isolated from backyard pigeons in some villages in El Qaluobeia governorate, Egypt during 2017 (PPQ 2017). Those pigeons were suffering from skin lesions on the eyelids, peak, and diphtheritic pox lesions on the upper respiratory tract. The affected pigeons have a moderate level of mortality reaching $15 \%$.

\subsection{Specific Pathogenic Free Embryonated Chicken Eggs}

Two hundred 10-12 days old, specific pathogenic free embryonated chicken eggs (SPF-ECE) were obtained from pox department, Veterinary Serum and Vaccine Research Institute (VSVRI), and used for propagation of the isolated virus and preparation of primary CEF cell culture.

\subsection{Preparation Of Chicken Embryo Fibroblast (CEF) Cell Culture}

Chicken embryo fibroblast cell cultures were prepared according to the method described by Bansal and Sing (1972) and Hernandez and Brown (2010) using 10 days-old- embryos. It was used for primary propagation of the isolated virus.

\subsection{Earle's Minimum Essential Medium (Mem)}

It was obtained from Sigma Chemical Company, USA and used as growth medium containing $10 \%$ Newborn calf serum or as maintenance medium containing $2 \%$ Newborn calf serum for CEF preparation, subculture and virus propagation on cell culture.

\subsection{Pigeon Pox Hyper-Immune Sera}

Hyper-immune sera against PPV were obtained from pox department, VSVRI, and used in Virus Neutralization Test for serological characterization of the isolated PPV

\subsection{Crystal Violet Stain}

It was used for staining normal and PPV infected CEF cells to reveal the cytopathic changes (CPE) according to Clayden (1971).

\subsection{DNA Extraction Kits}

GF-1 tissue DNA extraction kit (Vivantis, Malaysia) were used for DNA extraction from pock lesions of the propagated virus isolates inoculated on CAM of SPF-ECE.

\subsection{Primers pair used for amplification of P4b gene}

To amplify fragments of the P4b, two primer pairs (Fatma and Olla 2013) and (Sherif et al., 2015) were used (table 1).

\begin{tabular}{|c|c|c|c|}
\hline Primer & Orientation & Sequence & Specificity \\
\hline M2925 & Forward & 5`-CACAGGTGCTAAACAACAA -3` & P4b gene \\
\hline \multirow{2}{*}{ M2926 } & Reverse & 5`-CGGTAGCTTAACGCCGAATA -3 & P4b gene \\
\hline
\end{tabular}

Table1: Avian Pox Specific Primers Sequence

\section{Methods}

\subsection{Pigeon Pox Virus Propagation and Titration in SPF- ECE}

Virus propagation and titration on ECEs were performed following the procedure mentioned by OIE (2014). The virus isolate was inoculated onto CAM of SPF- ECE, the infected CAM with pock lesions were collected for virus extraction and further propagation for 7 successive passages. The propagated virus was titrated; the virus titre was calculated by Reed and Meunch (1938).

\subsection{Propagation and Titration of Pigeon Pox Virus CEF Cell Culture}

The virus isolate extracted from the inoculated CAM was reinoculated in primary CEF cell culture for 5 successive passages according to the method described by Mishra and Mallick (1994) and Olfat et al., (2005) 


\subsection{Virus Neutralization Test}

To confirm that the propagated virus was PPV, the virus neutralization test was applied on the isolated virus using specific hyper immune serum against PPV according to (OIE, 2014), and then the virus titre (VT) and the serum virus titre (SVT) were calculated by Reed and Meunch (1938). The neutralizing index (NI) was subsequently calculated as follows: NI = VT- SVT.

\subsection{DNA Extraction and PCR Amplification}

DNA was extracted from clarified suspension of isolated PPV propagated on ECE-CAM and CEF using GF-1 tissue DNA extraction kit (Vivantis, Malaysia) following manufacturer instructions. PCR amplification was performed in 50 $\mu$ l reaction volumes and contained $7 \mu \mathrm{l}$ of DNA template, $100 \mu \mathrm{M}$ of each deoxynucleoside triphosphate (Thermo Scientific, USA), 2.5 units of Dream Taq Green DNA polymerase (Thermosentific, USA), $5 \mu \mathrm{l}$ of amplification buffer and 20 Pmole of each primer. The PCR amplification was carried out using GeneAmp PCR system 9700 thermal cycler (Applied Biosystems, USA) and the cycling conditions illustrated in tables (2). PCR amplicons were analyzed by running $10 \mu \mathrm{l}$ of PCR reaction product in $1 \%$ agarose gel stained with Ethidium Bromide $(0.5 \mathrm{ug} / \mathrm{ml})$. Thereafter, gels were photographed under UV illumination using gel documentation and analysis system supplied with starlight express MX516 16-bit CCD camera and AAp-M5 software. The amplification pattern of each virus was determined according to molecular size of the amplified products.

\begin{tabular}{|c|c|c|c|}
\hline Steps & Temp & Time & No of cycles \\
\hline Initial denaturation & $95^{\circ} \mathrm{C}$ & $5 \mathrm{~min}$ & One cycle \\
\hline Denaturation & $95^{\circ} \mathrm{C}$ & $30 \mathrm{sec}$ & \multirow{2}{*}{35 cycles } \\
\hline Annealing & $50^{\circ} \mathrm{C}$ & $30 \mathrm{sec}$ & \\
\hline Extension & $72^{\circ} \mathrm{C}$ & $35 \mathrm{sec}$ & \\
\hline Final extension & $72^{\circ} \mathrm{C}$ & $7 \mathrm{~min}$ & \multirow{2}{*}{ One cycle } \\
\hline Preservation & $4^{\circ} \mathrm{C}$ & $\infty$ & \\
\hline
\end{tabular}

Table 2: Cycling protocol for amplification of P4b gene according to Fatma and

Ola (2013) and Sherif et al. (2015)

\subsection{Gel Purification and Sequencing of PCR Products}

Gel purification of the $578 \mathrm{bp}$ product, obtained from PPV isolate was performed using the QIAquick ${ }^{\circledR}$ Spin kit (Qiagen, Germany) following manufacturer instruction. The purified product was sequenced using the M2925 and M2926 forward and reverse primers to analyze the complete sequence of the $578 \mathrm{bp}$ amplified fragment. The obtained data were analyzed for similarities with Gene-Bank published sequences using the Basic Local Alignment Search Tool (BLAST) before further analysis using Bioedit ${ }^{\circledR}$ and MEGA5 ${ }^{\circledR}$ software packages.

\section{Results}

\subsection{Virus Isolation, Propagation and Titration in SPF- ECE}

Skin lesions of suspected diseased pigeon (photo 1) were collected and processed to isolate, propagate, and titrate pox virus on SPF-ECE. Pock lesions were detected at the 3rd passage (photo 2) with moderate thickening in the CAM with few yellowish white colored pock lesions.

The virus titre of the isolated PPV reached $4.5 \log _{10} \mathrm{EID}_{50} / \mathrm{ml}$ at the $6^{\text {th }}$ passage as shown in table (3)

\begin{tabular}{|c|c|}
\hline No of Passage & Virus Titre Log $_{\mathbf{1 0}}$ EID $_{\mathbf{5 0}} / \mathbf{M l}$ \\
\hline 3rd passage & 3.0 \\
\hline $4^{\text {th }}$ passage & 3.5 \\
\hline $5^{\text {th }}$ passage & 4.0 \\
\hline 6 $^{\text {th }}$ passage & 4.5 \\
\hline 7th $^{\text {th }}$ passage & 4.5 \\
\hline
\end{tabular}

Table 3 


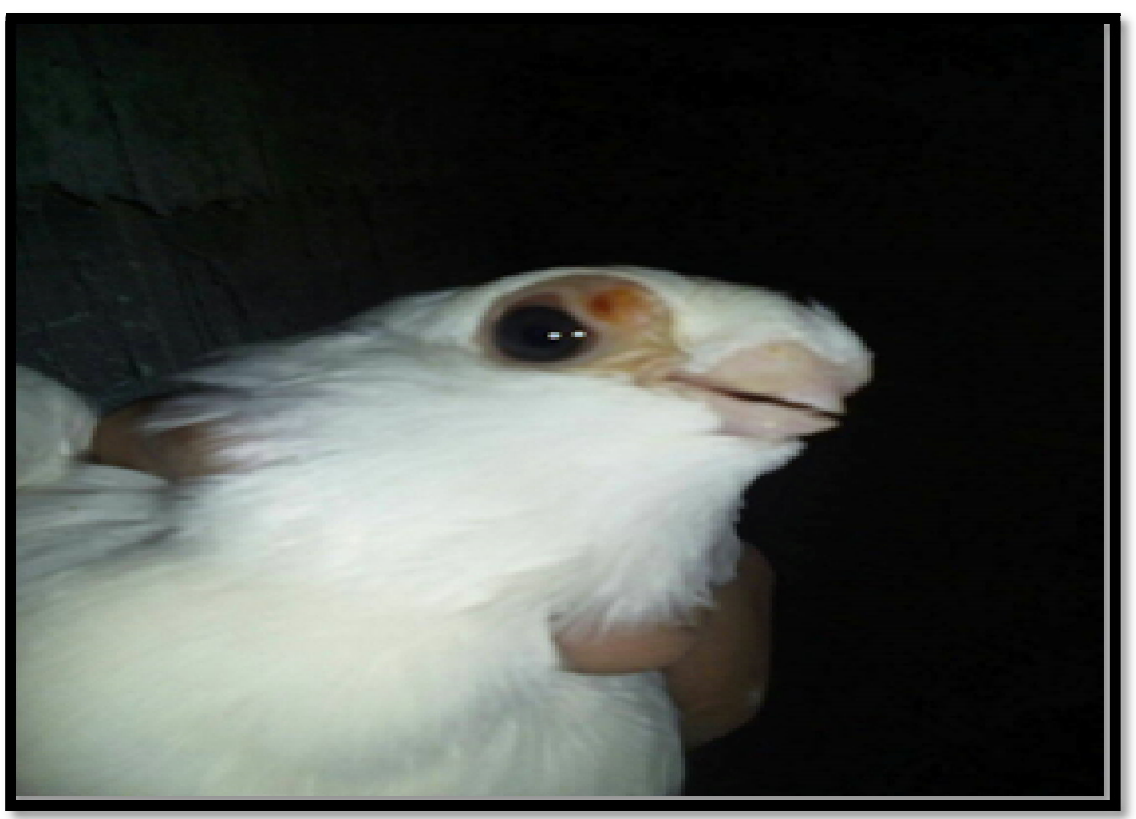

Figure 1: Skin Pox Lesion in Pigeon: A Case of Pigeon Showing Characterizing Lesions of Poxvirus Infection around the Eyelids and Nostrils, These Were Scraped and Forwarded o Virus Isolation

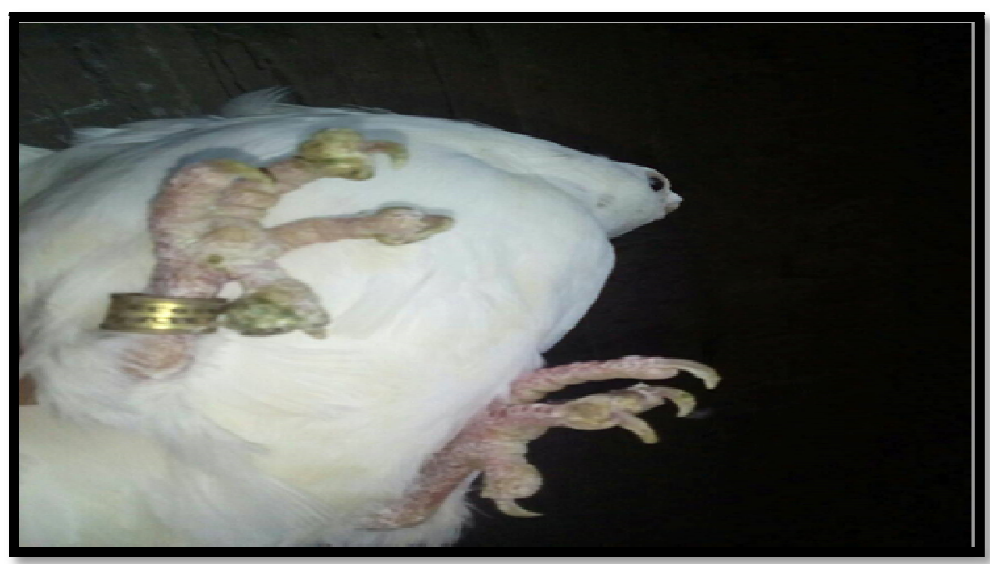

Figure 2

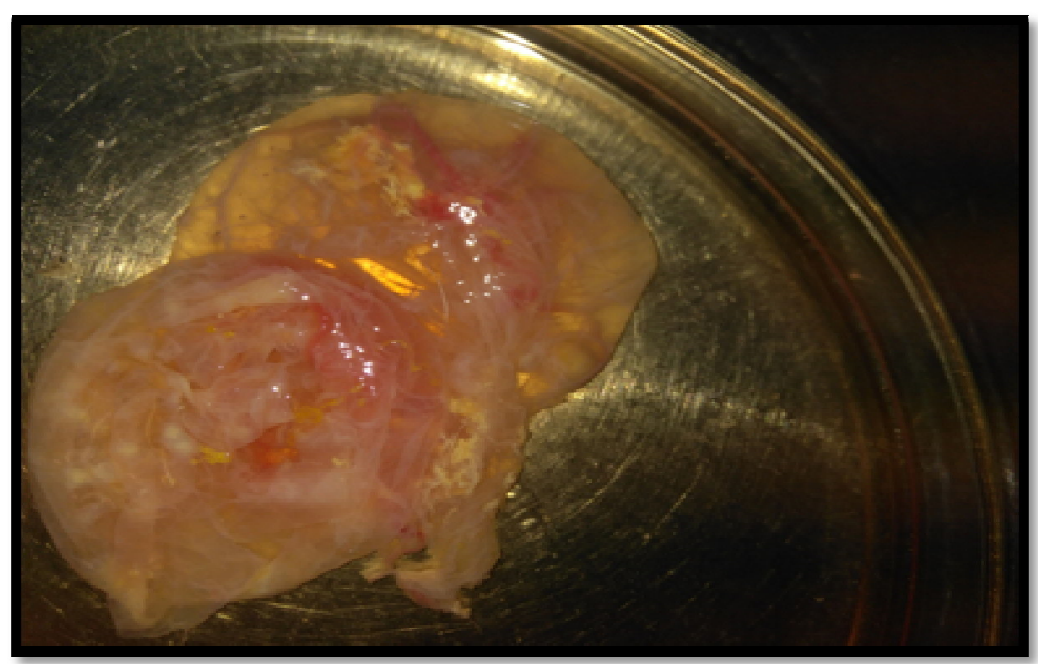

Figure 3: Pock Lesions of Pigeon Pox Virus on CAM of ECE 
A few numbers of widely scattered white colored pock lesions induced by PPV were detected at the $5^{\text {th }}$ passage of inoculated ECE.

\subsection{Propagation and Titration of Isolated PPV on CEF}

Propagation of isolated PPV in CEF revealed that the virus CPE appeared clearly at the 3rd passage after 6-day post inoculation and on the $5^{\text {th }}$ day post inoculation by the $4^{\text {th }}$ passage with titre $4.0 \log _{10} \mathrm{TCID}_{50} / \mathrm{ml}$, at the end of study at $5^{\text {th }}$ passage the titre was $4.3 \log _{10} \mathrm{TCID}_{50} / \mathrm{ml}$ as shown in table (4). The CPE was observed as rounded and degenerated cells with vacuolation and cell aggregations as shown in photos (4 and 5).

\begin{tabular}{|l|l|l|}
\hline \multicolumn{1}{|c|}{ Virus passage } & Harvestation time & \multicolumn{1}{c|}{$\begin{array}{c}\text { Virus titre } \log _{\mathbf{1 0}} \\
\text { TCID }_{\mathbf{5 0}} / \mathbf{m} \mathbf{l}\end{array}$} \\
\hline 1 & 6 & - \\
\hline 2 & 6 & - \\
\hline 3 & 6 & 3.0 \\
\hline 4 & 5 & 4.0 \\
\hline 5 & 5 & 4.3 \\
\hline
\end{tabular}

Table 4: Titration and Harvestation Time of the Propagated Virus on CEF

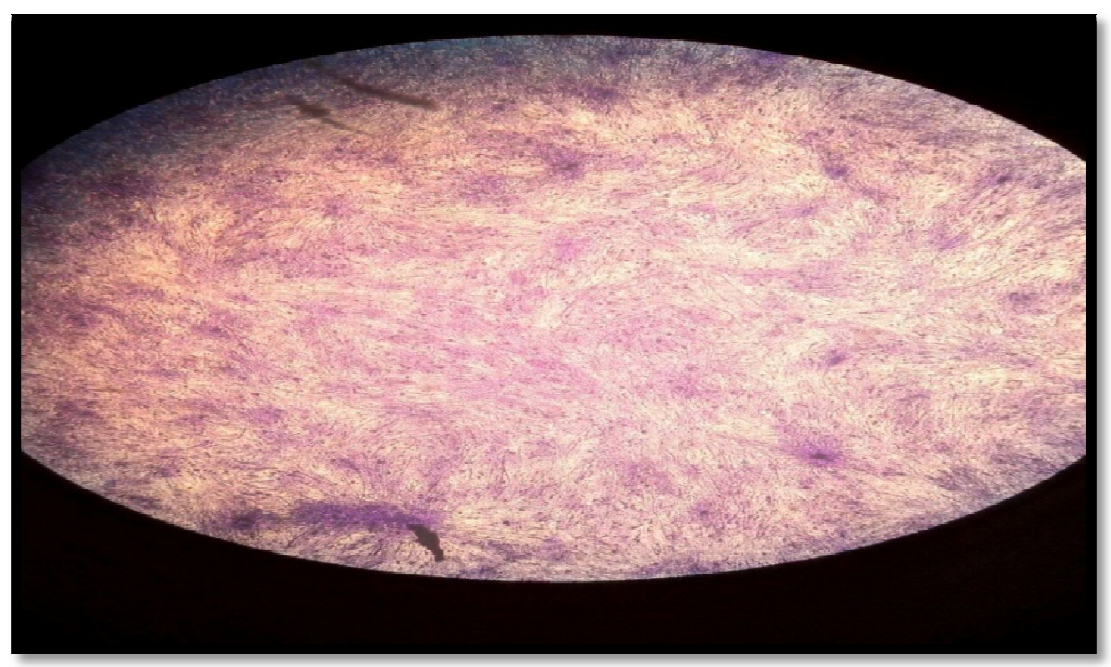

Figure 5: Low Power Healthy Spindle Normal CEF Cells

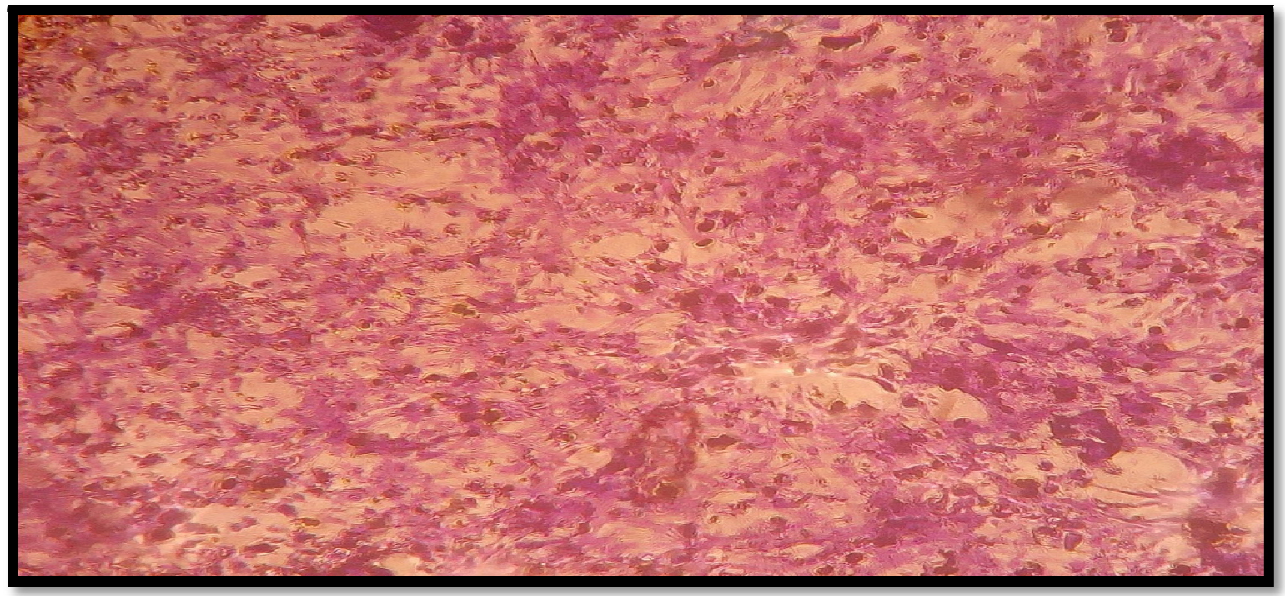

Figure 6: High Power CPE of Propagated PPV on CEF Showing Rounding of Cells, Cell Detachment, Intracytoplasmic Inclusion Bodies and Giant Cell Formation 


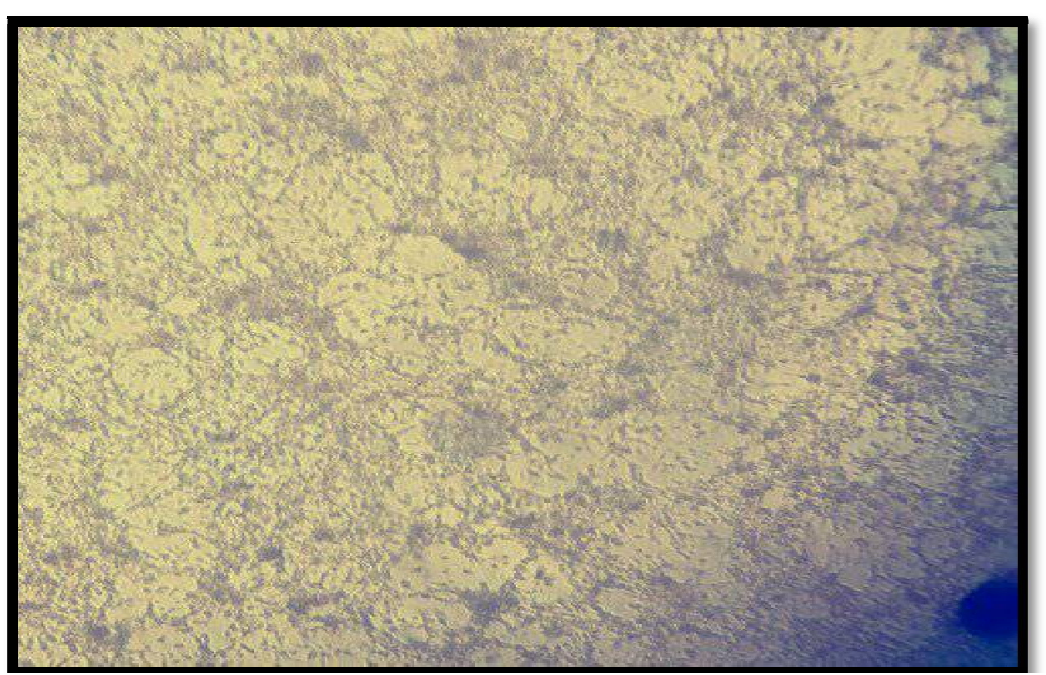

Figure 7: Low Power CPE of PPV Propagated on CEF

Showing Cell Rounding, Aggregation and Detachment of the Cells

\subsection{Virus Neutralization Test on CEF}

Alpha procedure of neutralization test (fixed serum and variable virus dilution) was carried on the isolated PPV adapted on CEF using anti- pigeon pox hyper immune sera (PPHIS) showing reduction in virus titre with $2.5 \mathrm{NI}$ as shown in table (5).

\begin{tabular}{|c|c|c|c|}
\hline Isolated Virus & Virus Titre & VNT With PPHIS & \multirow{2}{*}{$\begin{array}{c}\text { NI With } \\
\text { PPHIS }\end{array}$} \\
\cline { 2 - 3 } & \multicolumn{2}{|c|}{ Titre expressed as $\log _{10} \mathrm{TCID}_{50} / \mathrm{ml}$} & 2.5 \\
\hline PPV isolate & 4.5 & 2.0 & 2.0 \\
\hline
\end{tabular}

Table 5: Results of VNT for PPV Isolated and Propagated on CEF

VNT: Virus neutralization test

PPHIS: pigeon pox hyper immune sera

$\mathrm{TCID}_{50}$ : tissue culture infective dose 50

NI: neutralizing index

\subsection{Polymerase Chain Reaction (PCR) For P4b Gene Of PPV}

Polymerase chain reaction was applied on the DNA extracted from propagated PPV isolate using P4b gene forward and reverse specific primers (Jarmin et al., 2006). PCR amplification of the tested samples revealed the specific PCR amplicons of $578 \mathrm{bp}$ for $\mathrm{P} 4 \mathrm{~b}$ as shown in photo 8.

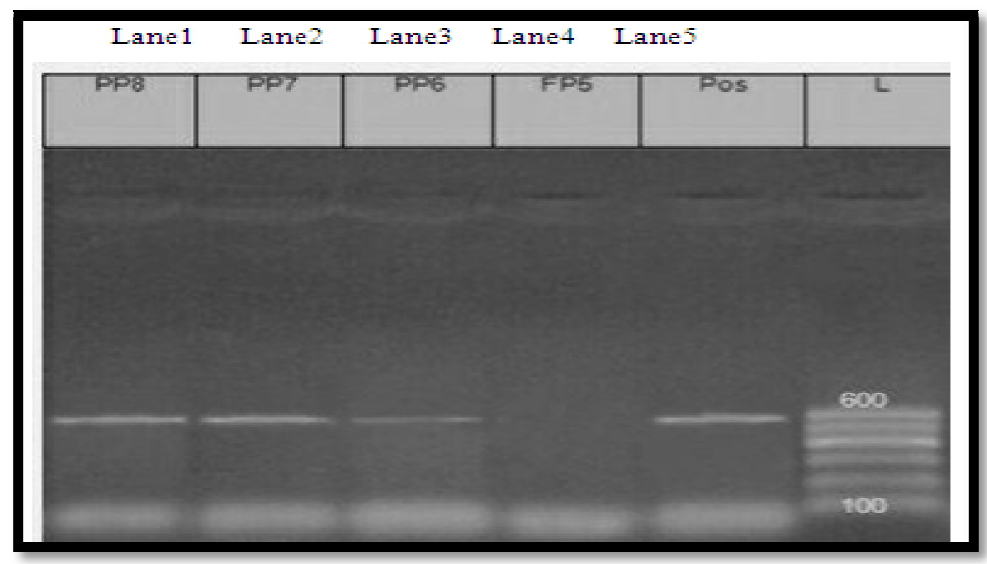

Figure 8: PCR Amplified Products for P4b Gene 
L - 600 b DNA ladder 100 to 600 bp. Lane 1-PP8- amplification product from crust sample. Lane 2- PP7 amplified product for the isolated virus propagated on ECE. Lane 3- PP6- amplified product for the isolated virus propagated on CEF. Lane 4- amplified product for negative control. Lane 5- amplified product for positive control PPV.

\subsection{Phylogenetic and Alignment Analysis of P4b Gene}

The nucleotides sequence alignment of 578 nucleotides (truncated to have the same length) PPV isolate amplicon, was performed using MEGA6 software package. The obtained sequences were aligned with the published APVs-P4b nucleotides sequences, including CNPV, of which were used as reference strains in sequence analysis

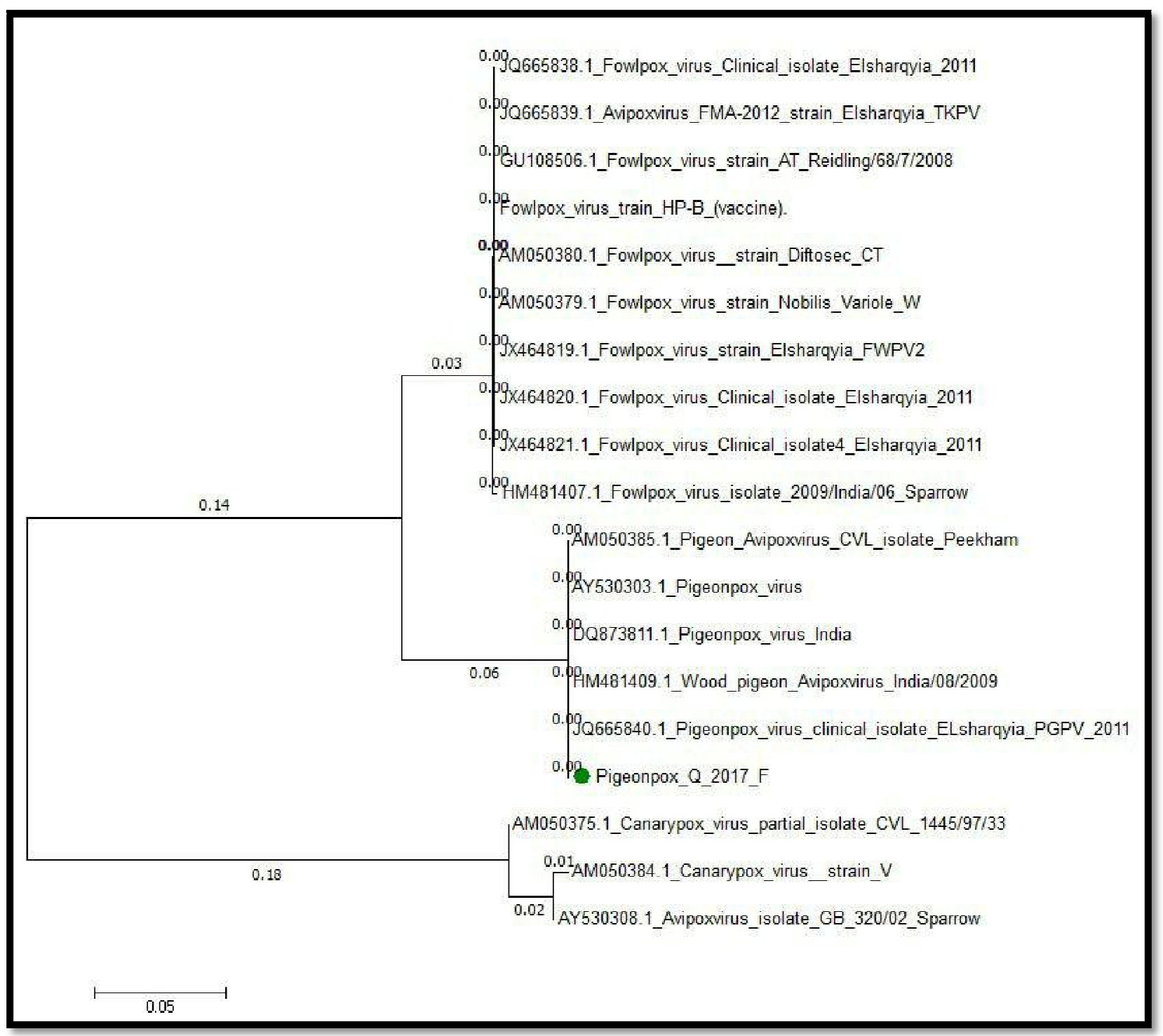

Figure 9

Figure (9): Phylogenetic tree of P4b gene sequences. Nucleotide sequences of the obtained amplicons were aligned with a panel of FPV, PPV, and CNPV sequences obtained from the gene bank with gene bank accession numbers written at each branch. Sequences were distributed into two major clades A and B. While clade A included two clusters forming Geno groups A1 and A2, one cluster formed clade B. As expected, local isolates of FPV of gene bank were clustered in Geno group A1, while PPV isolate namely pigeon pox Q 2017 was clustered at the same Geno group A2 with other local isolate present in the gene bank. CNPV were clustered forming Geno group B 


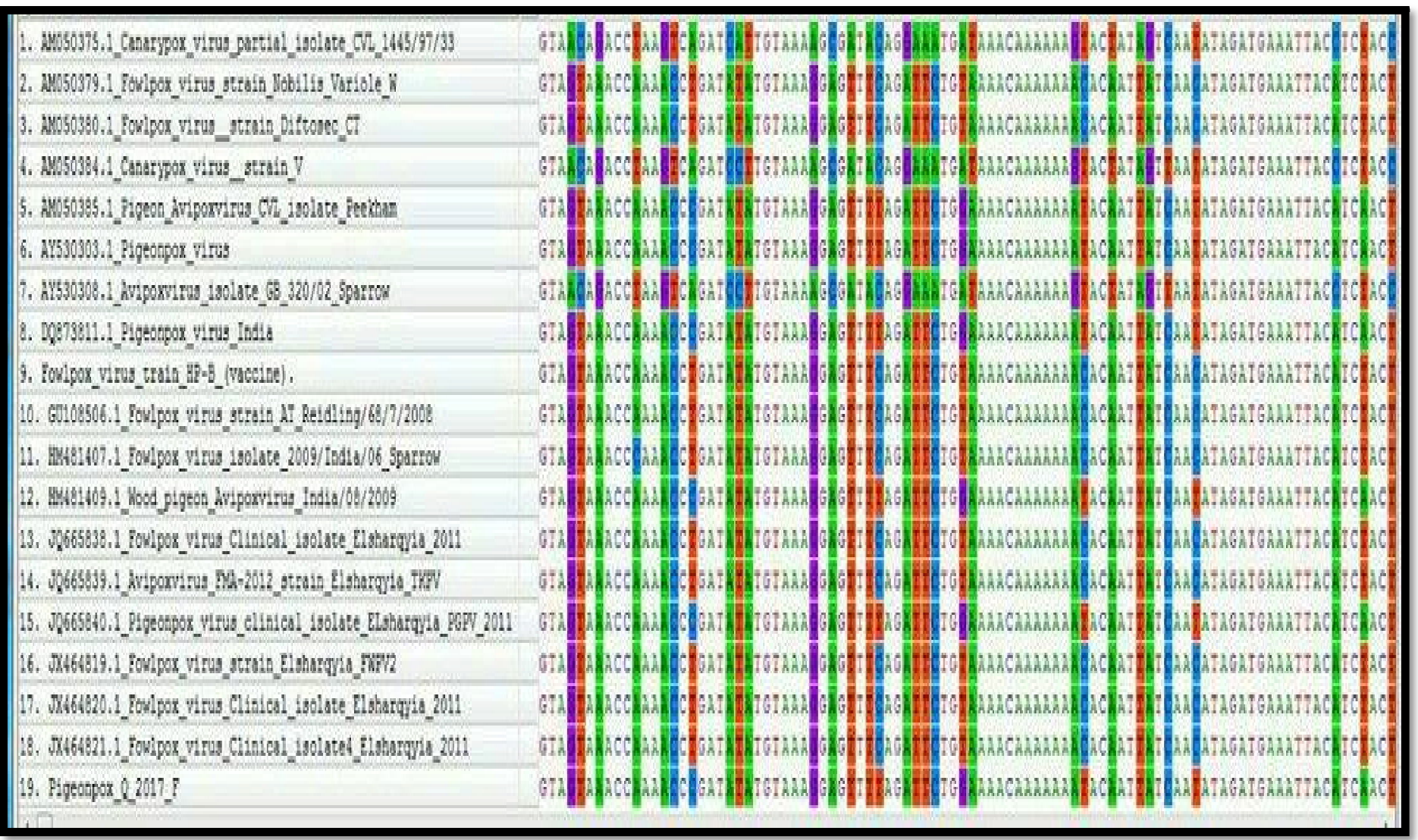

Figure 10: Nucleotide Sequence Alignment of P4b Amplicons. Alignment of the 578 Bp Amplicons Obtained from PCR Reactions Using M2925 and M2926 Primers Revealed That the Isolated Pigeon Pox Q Virus Showed a Complete Matching with Pigeon Pox Viruses Recorded in Gene Bank (Part 1)

\begin{tabular}{|c|c|}
\hline 1. AM050375.1 Canarypox virus partial 1solate CVI $1445 / 97 / 33$ & \\
\hline 2. AM050379.1_Fonlpor_virus_atrain_Wobilis_Variole_W & \\
\hline 3. AM050380.1_Foulpox_virus_atrain_Difteoee_CI & \\
\hline 4. AM050384.1_Canarypox_virus_atrain_V & \\
\hline 5. ANo50385.1_Pigeon_Avipoxvirus_CVL_isolate_Peekham & \\
\hline 6. AY530303.1_P1geonpox_v1rus & \\
\hline 7. AY530300.1_Avipoxvirua_1aolate_GB_320/02_Sparrow & \\
\hline 8. Do873811.1_Figeanpos_virus_India & \\
\hline 9. Fowlpox_virus_train_HP-B_(vaccine). & \\
\hline 10. GU108506.1_Fow1pox_vifus_strain_AI_Reiding/68/7/2008 & \\
\hline 11. HA4a1407.1_Fow1pox_virua_1301ate_2009/India/06_Sparrow & \\
\hline 12. HM481409.1_Wood_pigeon_Aviporvirus_India/08/2009 & \\
\hline 13. JQ665838.1_Fow1pox_virua_Clinical_isolate_Elaharqyia_2011 & \\
\hline 14. J0665839.1_Aviporvirus_FMA-2012_3train_Elsharqyia_IKFV & \\
\hline 15. JQ665840.1_Pigeonpox_Virua_clinical_laolate_ELharqVia_PGPV_2011 & \\
\hline 16. JX464819.1_Fow1pox_Virua_strain_Elaharqyia_FWFV2 & \\
\hline 17. JX464820.1_Fowlpox_virua_Clinical_isolate_Elaharqyia_2011 & \\
\hline 18. JX464821.1_Fow1pox_virug_Clinical_fsolate4_ElaharqYia_2011 & \\
\hline 19. Pigeonpox_Q_2017_F & \\
\hline
\end{tabular}

Figure 11: Nucleotide Sequence Alignment of P4b Amplicons. Alignment of the 578 Bp Amplicons Obtained from PCR Reactions Using M2925 and M2926 Primers Revealed That the Isolated Pigeon Pox Q Virus Showed a Complete Matching with Pigeon Pox Viruses Recorded in Gene Bank (Part 2) 


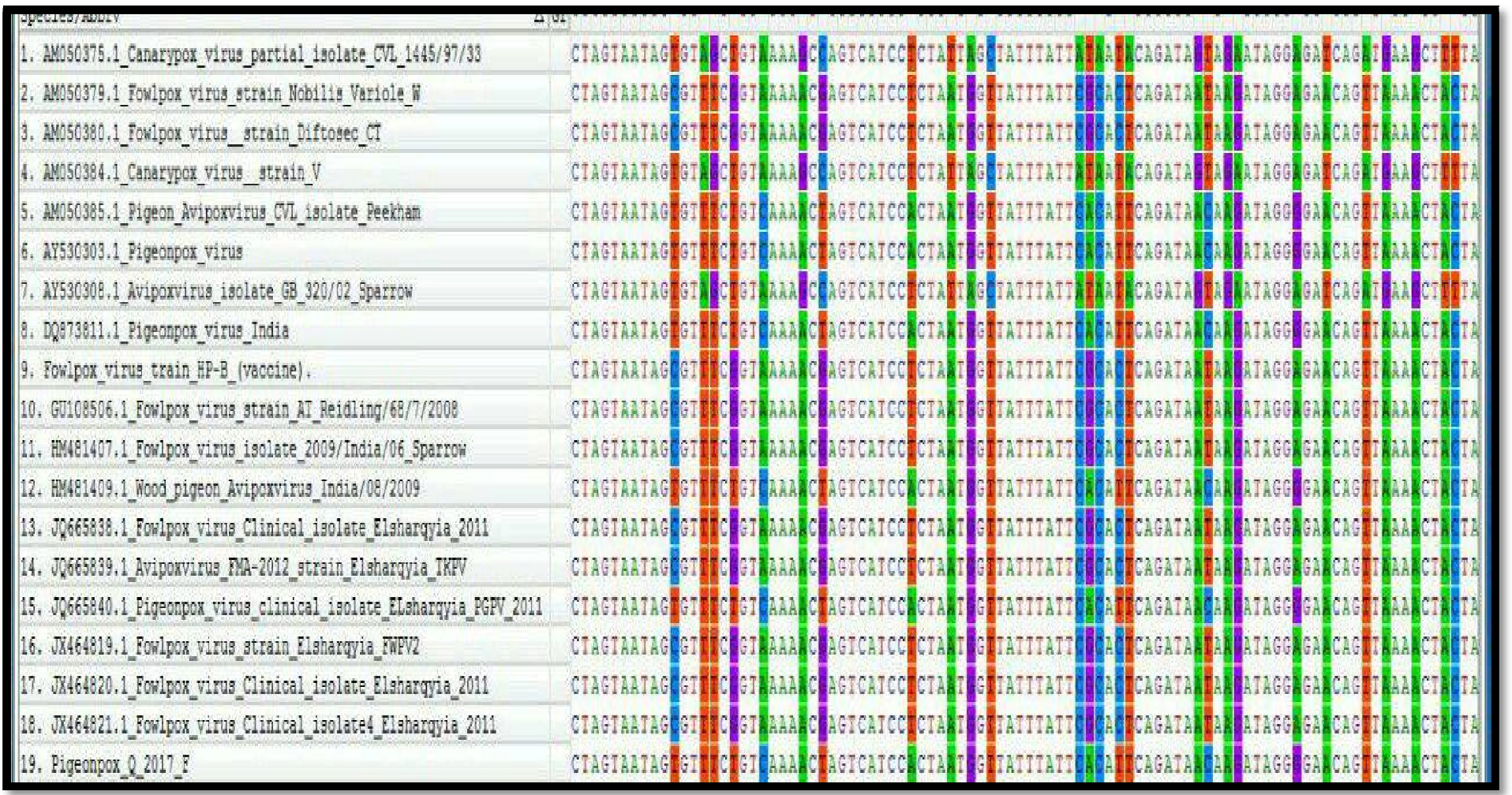

Figure 12: Nucleotide Sequence Alignment of P4b Amplicons. Alignment of the 578 Bp Amplicons Obtained from PCR Reactions Using M2925 and M2926 Primers Revealed That the Isolated Pigeon Pox Q Virus Showed a Complete Matching with Pigeon Pox Viruses Recorded in Gene Bank (Part 3)

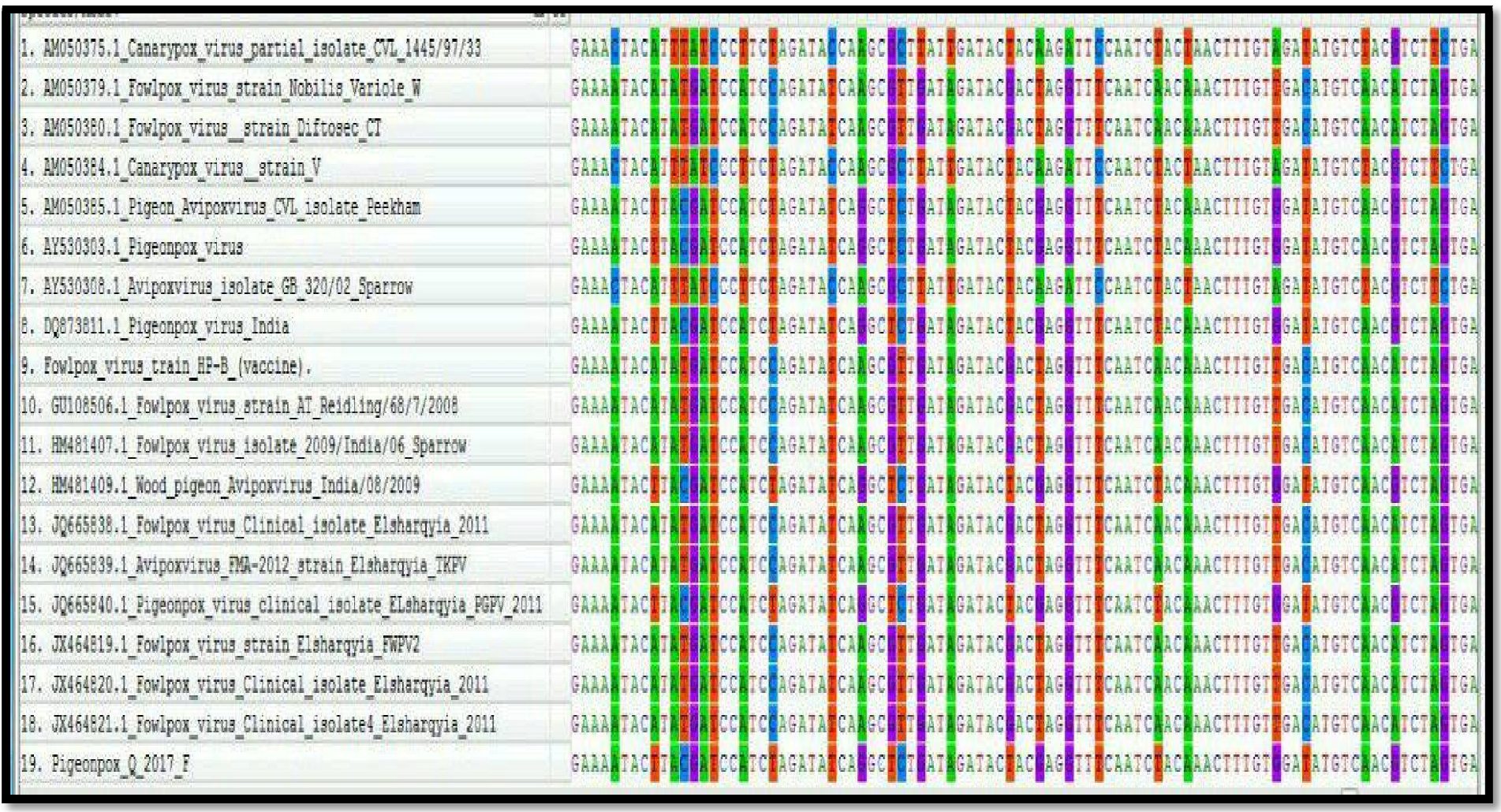

Figure 13: Nucleotide Sequence Alignment of P4b Amplicons. Alignment of the 578 Bp Amplicons Obtained from PCR Reactions Using M2925 and M2926 Primers Revealed That the Isolated Pigeon Pox Q Virus Showed a Complete Matching with Pigeon Pox Viruses Recorded in Gene Bank (Part 4) 


\begin{tabular}{|c|c|}
\hline 1. AM050375.1_Canarypor_virus_partial_isolate_CVL_1445/97/33 & IAI ICI II \\
\hline 2. AM050379.1_Fowlpox_Virus_strain_Nobilis_Variole_W & IIIAGAII \\
\hline 3. AM050380.1_Fowlpox_virus_strain_Diftosec_CT & IATEIATIIAGATIC \\
\hline 4. AM050384.1_Canarypox_virus_strain_V & GAITC \\
\hline 5. AM050385.1_Pigeon_Avipoxvirus_CVL_isolate_Peekham & I IIAGAII \\
\hline 6. AY530303.1_Figeonpox_virus & I IIIAGAI \\
\hline 7. AY530308.1_Avipoxvirus_isolate_GB_320/02_Sparrow & I IIIAGATC \\
\hline 8. DQe73811.1_Figeonpox_virus_India & IFIIAGAT: \\
\hline 9. Fowlpox_virus_train_HP-B_(vaccine). & IATIAGATI \\
\hline 10. GU108506.1_Fowlpox_virus_strain_AI_Reidling/68/7/2008 & IIIAGAII \\
\hline 11. HM481407.1_Fowlpon_virus_isolate_2009/India/06_Sparrow & IAT I I I I A GAIT CARAGACCA \\
\hline 12. HM481409.1_Wood_pigeon_Avipoxvirus_India/08/2009 & I IIIAGAII \\
\hline 13. JQ665838.1_Fowlpox_virus_Clinical_isolate_Elsharqyia_2011 & IAIIIAGAITE \\
\hline 14. JQ665839.1_Avipoxvirus_FMA-2012_strain_Elsharqyia_IKPV & IIAGAII \\
\hline 15. JQ665840.1_Pigeonpox_Virus_clinical_isolate_ELsharqyia_PGPV_2011 & IAIIIIIIAGAIID \\
\hline 16. JX464819.1_Fowlpox_virus_strain_ElsharqYia_FWPV2 & IAI IIAIIIAGAIC \\
\hline 17. JX464820.1_Fowlpox_virus_Clinical_isolate_Elsharqyia_2011 & IATIAGATE \\
\hline 18. JX464821.1_Fowlpox_virus_Clinical_isolate4_Elsharqyia_2011 & IAIFIAIIIAGAIICAAAGACGA \\
\hline 19. Pigeonpox_Q_2017_E & IIIAGAT \\
\hline
\end{tabular}

Figure 14: Nucleotide Sequence Alignment of P4b Amplicons. Alignment of the 578 Bp Amplicons Obtained from PCR Reactions Using M2925 and M2926 Primers Revealed That the Isolated Pigeon Pox Q Virus Showed a Complete Matching with Pigeon Pox Viruses Recorded in Gene Bank (Part 5)

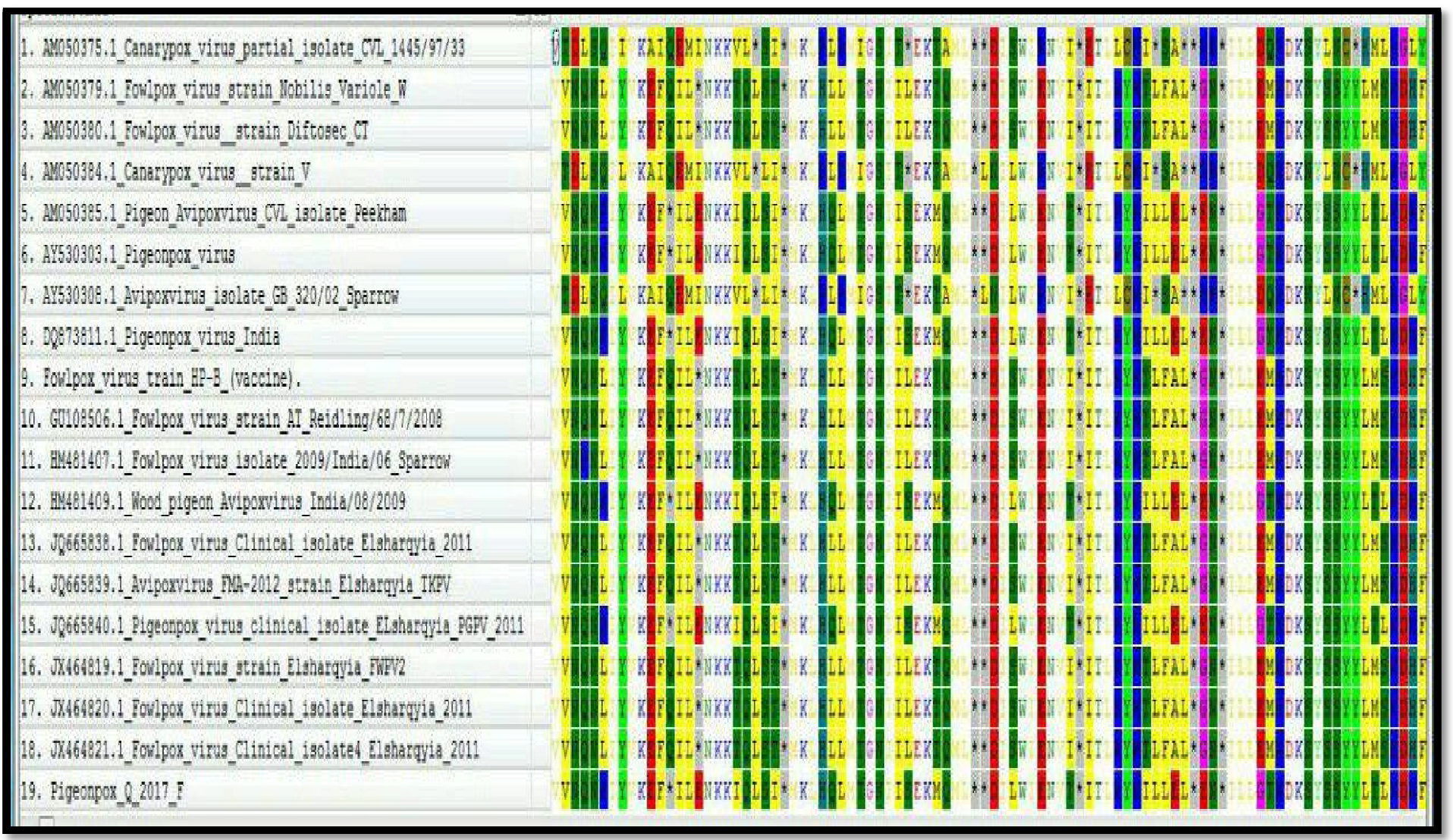

Figure 14: Amino Acid Sequence Alignment of P4b Amplicons Revealed That Pigeon Pox Q Showed a Complete Matching with Pigeon Pox Viruses with Gene Bank (Part 1) 


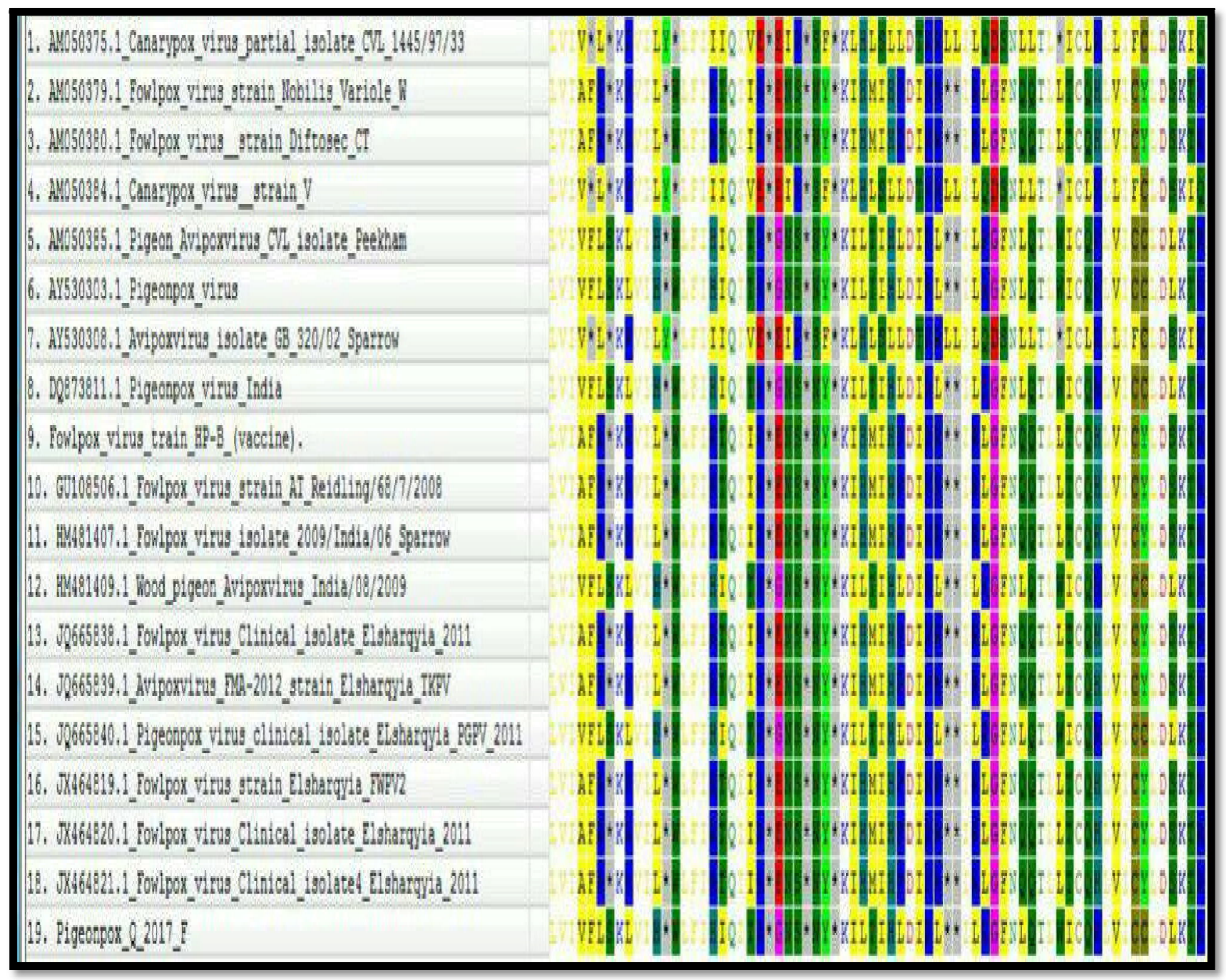

Figure 15: Amino Acid Sequence Alignment of P4b Amplicons Revealed That Pigeon Pox Q Showed a Complete Matching with Pigeon Pox Viruses with Gene Bank (Part 1)

\section{Discussion}

Pigeon pox is a serious virus disease in pigeon causing mortalities especially in young pigeon characterized by the development of discrete proliferative nodular skin lesions (cutaneous form) or fibrino-necrotic lesion in the mucous membrane of the upper respiratory tract (diphtheritic form) (Sumaya 2005).

At the present study, the PPV was isolated from affected pigeon showing the symptoms of pigeon pox as vesicles, papules and crusts on head and legs as previously described by Hemanth et al. (2014). Firstly, the local isolate was propagated and titrated on CAM showing the characteristic scattered pock lesions for PPV, where thickening of the CAM was deducted in the first two passages, small sized pock lesions were increased in number and size with serial passaging in ECE as few yellowish white colored and large sized pock lesions appeared. As shown in photo (2) with moderate thickening in the CAM as described by Fatma and Olla, (2013), Sivasothy (1997) and Sherif et al., (2015). They also reported that PPV pock lesion characterized by its large size and yellowish white coloration than other pock lesion from other APVs (fowl and canary).

Regarding virus titre, the titre of the PPV was $3.0 \log _{10} \mathrm{EID}_{50} / \mathrm{ml}$ at the $3^{\text {rd }}$ passage reaching $4.5 \log _{10} \mathrm{EID}_{50} / \mathrm{ml}$ at the $6^{\text {th }}$ passage on ECE which come in accordance with the results obtained by Sherif et al., (2015) who mentioned that the isolates from pigeon and turkey gave lower titre in comparison with other isolates from chickens on (CAM) giving titre of $4.0 \log _{10}$ $\mathrm{EID}_{50} / \mathrm{ml}$.

Propagation of isolated PPV on CEF revealed that CPE appeared clearly at the $3^{\text {rd }}$ passage after 6-day post inoculation with titre $3.0 \log _{10} \mathrm{TCID}_{50} / \mathrm{ml}$ and then reached complete CPE on the $5^{\text {th }}$ day post inoculation by the $4^{\text {th }}$ and $5^{\text {th }}$ passages as the virus titre reached $4.3 \log _{10} \mathrm{TCID}_{50} / \mathrm{ml}$. The CPE was observed as rounded and degenerated cells, cell aggregations with vacuolation, intracytoplasmic inclusion bodies and giant cell formation as shown in photos (4 and 5). Confirming to the obtained data by Olfat et al., (2005) as gradual appearance of CPE was observed by the $3^{\text {rd }}$ passage and appeared after the 5 th day with $5 \log _{10} \mathrm{TCID}_{50} / \mathrm{ml}$. 
The virus neutralization test (VNT) was performed in CEF as shown in table (5) where reduction of the titre of the isolated pigeon pox virus using anti- pigeon pox hyper immune sera (PPHS) was $2.5 \mathrm{NI}$ which indicated the high relationship for the isolated virus to PPV. Similar results obtained by, Hemanth et al. (2014), Sherif et al. (2015) and Sumaya (2005) who detected a high immunological relationship between PPV and its homologues hyperimmune sera than the using of heterologous hyper immune sera of FPV.

However, and up till now, there was no available record of the molecular composition of APVs circulating in Egypt. Most of our knowledge concerning the avian pox viruses is based on clinical forms Fatma and Olla (2013). In this study, a small-scale survey was conducted to understand the nature of PPV isolated from different backyards at the molecular level to help identifying novel threats facing pigeons.

For genomic characterization PCR amplification were applied on the collected skin crust and the propagated PPV on CAM and CEF for the P4b gene revealed the highly conserved 578-bp APV-specific DNA fragment for PPV isolates. Based on the length of the amplicons, similar results obtained by Jarmin et al. (2006), Soad et al. (2007), Manarolla et al. (2010) and Offerman et al. (2014). The results of P4b gene sequencing revealed that there is similarity 99\% between isolated PPV and PPV isolates recorded in gene bank as no nucleotide deletion or insertion.

The phylogenic analysis of the isolated propagated PPV to other PPV isolates in gene bank and sequencing of the P4b578-bp DNA fragment was performed on PPV isolates followed by Basic Local Alignment Search Tool (BLAST) revealed that isolated propagated pigeon virus belonged to the major clade $\mathrm{A}$, and clustered with pigeon pox virus strains (accession numbers JQ665840 [El-Sharqya strain], AY530303, KJ913659, and DQ873811) at subclade A2. This distribution comes in accordance with the data obtained from the BLAST analysis where PPV isolate showed a close identity of 99\% with pigeon pox sequences in the gene bank (JQ665840- El-Sharqya strain). These results are in parallel with Jarmin et al. (2006), Luschow et al. (2004) and Fatma and Ola. (2013) who reported that PPV isolates clustered within subclade A2 and FPV isolates clustered within subgroup A2 while Canary pox virus clustered within Clade B.

The present study reports that the local isolate of PPV was identified using serological test (SNT) and PCR followed by nucleotide sequence analysis for the P4b gene which revealed the identity between the isolated PPV and other reported PPV isolates in gene bank.

Also, this study recommended further immunological investigation on the isolated pigeon pox virus to facilitate the production of PPV vaccine from the locally isolated strain.

\section{References}

i. Andraw, K. (2012): Virus taxonomy: ninth report of the international committee on the taxonomy of viruses. The international committee on taxonomy of international union of microbiological societies. Pp.298.

ii. Bansal, M.P. and Singh, M.P. (1972): Multiplication of fowl pox virus in chicken embryo fibroblast cultures. Ind. J. Microbiol., 12 (2): 115-117

iii. Clayden, E, C. (1971): Practical Staining 5th edition. Edinburgh and loudin, 7: 244-246

iv. Fatma M. Abdallah and Ola. F. H (2013): Detection and molecular characterization of avipoxviruses isolated from different avian species in Egypt. Virus Genes (2013) 46:63-70.

v. Hemanth I, Amaravathi P, Sasidhar Babu N, Anand Kumar A and Sailaja N (2014): An out-break of cutaneous form of avian pox in pigeons (columbia livia) International Journal of Science, Environment and Technology, Vol. 3, No 4, 1484 1488.

vi. Hernandez R1, Brown DT (2010): Growth and maintenance of chick embryo fibroblasts (CEF). Curr Protoc Microbiol. 2010 May;Appendix 4:4I. doi: 10.1002. mca04is17.

vii. Islam MR, Khan MSR, Islam MA, Kayesh MEH, Karim MR, Gani MO and Kabir A (2008): Comparative efficacy of imported fowl pox virus vaccine with locally produced one in backyard chicks. Bangl. J. Vet. Med.6 (1):23-26.

viii. Jarmin, R. Manvell, R.E. Gough, S.M. Laidlaw, M.A and Skinner. S, (2006): A vipoxvirus phylogenetics: identification of a PCR length polymorphism that discriminates between the two major clades. J. Gen. Virol. 87, 2191-2201

ix. Khan A, Yousaf A, Khan MZ, Siddique M, Gul ST, Mahmood F (2009): Cutaneous form of pox infection among captive peafowl (Pavocristatus) chicks. Avian Pathol. 38(1):65-70.

x. Luschow. D, Hoffmann, T and Hafez H.M. (2004): Differentiation of avian poxvirus strains on the basis of nucleotide sequences of $4 \mathrm{~b}$ gene fragment. Avian Dis.: 48, 453-462.

xi. Manarolla, G; Pisoni, G; Sironi, G and Rampin, T (2010): Molecular biological characterization of avian poxvirus strains isolated from different avian species. Vet Microbiol., 6, 140: 1-8.

xii. Mishra, S.S.: and Mallick, B.B. (1994): Structural proteins of fowl poxvirus vaccine strain and field isolates. Indian Journal of Experimental Biology. Vol. 32: 826-831.

xiii. Olfat.E.Nakhla, Mervat. M. Ali, Micheal. And Soad. M. Soliman (2005): Adaptation and propagation of the Egyptian strain of pigeon pox on different types of cell cultures. J Vet Med Ass. Vol. (65) pages 191-202.

xiv. Offerman K, Carulei O, Gous T, Douglass N and Williamson AL (2014): Phylogenetic and histological variation in avipox viruses isolated in South Africa. J. Gen. Vir., 94:2338-2351.

xv. Office International Des Epizootic (OIE) (2014): Recommended Diagnostic Technique and Requirements for biological products, Volume 1 (chapter 2.3.9. pp 507-514). 
xvi. Reed, L. J. and Meunch, H (1938): A simple method of estimating fifty percent end points. Am. J. Hyg, 27:493-497. Ref. for pock lesions.

xvii. Sivasothy A. (1997): Characterization and pathogenicity studies of Malaaysaian isolates of avian pox virus MD Thesis, Poultry Dep., Fac. Vet. Med., Universiti Putra Malaysia

xviii. Soad, M. S.: Abd El-Razik, B. A: Amal, F: Amira, A.E and Micheal, A. (2007): Antigenic comparative studies between vaccinal and virulent strains of pigeon pox viruses Zag. Vet.J. Vol (35), No. (1) PP 8-13.

xix. Sherif M. I, Abd El-Razek. B., Hanan M. E., Amal. A. F and Ayatollah. I. (2015): Comparative molecular study on avian pox viruses. Egyption J.virol.Vol.12 PP:12-21.

xx. Sumaya k. Khogali (2005): Pathogenic antigenic and serologic relationship between fowl pox, pigeon pox and canary pox viruses M.V.Sc., U. of K Weli, S.C., Tryland, M. (2011): Avipox viruses: infection biology and there use as vaccine vectors. Virol. 8, 49-56. 